\title{
Reconstrução do Dorso da Mão com Retalho Bilobulado: Uma Opção Cirúrgica Incomum
}

\section{Bilobed Flap for Surgical Reconstruction of the Dorsum of the Hand: An Uncommon Surgical Option}

Ermelindo Tavares ${ }^{1}$

Autor Correspondente: Ermelindo Tavares [tavares.ermelindo@gmail.com] Estrada Carlos Lima Costa n² 2, Povos, 2600-009 Vila Franca de Xira, Portugal

PALAVRAS-CHAVE: Lesões da Mão/cirurgia; Procedimentos Cirúrgicos Reconstrutivos; Retalhos Cirúrgicos KEYWORDS: Hand Injuries/surgery; Reconstructive Surgical Procedure; Surgical Flaps

\section{RELATO DE CASO}

Mulher de 89 anos, caucasiana, observada por nódulo ulcerado no dorso da mão direita, com $25 \times 20$ mm de dimensões e cinco meses de evolução (Fig. 1). Negava dor e não tinha aderência aos planos profundos, limitação na mobilidade digital e adenopatias regionais palpáveis. A biópsia revelou carcinoma espinocelular (CEC) moderadamente diferenciado.

A lesão foi excisada sob anestesia local com margem lateral de $10 \mathrm{~mm}$, tendo-se gerado um defeito cirúrgico circular com $45 \times 40$ mm (Fig. 2). Procedeu-se ao seu encerramento com retalho bilobulado (BL) (Fig. 2). O lóbulo principal media cerca de $70 \times 25 \mathrm{~mm}$ (comprimento x largura) e foi dissecado a partir do dorso da primeira articulação metacarpofalângica. O secundário tinha cerca de $50 \times 15$ mm e foi obtido a partir do 1/3 distal do antebraço. Os lóbulos formavam entre si um ângulo aproximado de $105^{\circ}$. Os retalhos foram transpostos, adaptados e integrados nos defeitos e a zona dadora foi encerrada diretamente.

O exame histológico confirmou CEC moderadamente diferenciado, sem invasão vascular e nervosa, tendo a excisão sido completa. Os resultados estéticos e funcionais foram aceitáveis três meses depois (Fig. 3). A doente mantém-se sem recidiva aos 12 meses de seguimento.

O retalho BL é um retalho de transposição randomizado utilizado frequentemente na reconstrução da face, sendo o nariz a unidade mais beneficiada. A sua versatilidade tem permitido ampla aplicação extra facial, em particular nas extremidades e no tronco. ${ }^{1-3}$ Embora incomum, este retalho pode ser uma opção na reconstrução do dorso da mão onde, tal como acontece na ponta nasal, é vantajoso atendendo à mobilidade reduzida dos tecidos adjacentes. Os defeitos de pequenas, médias e 


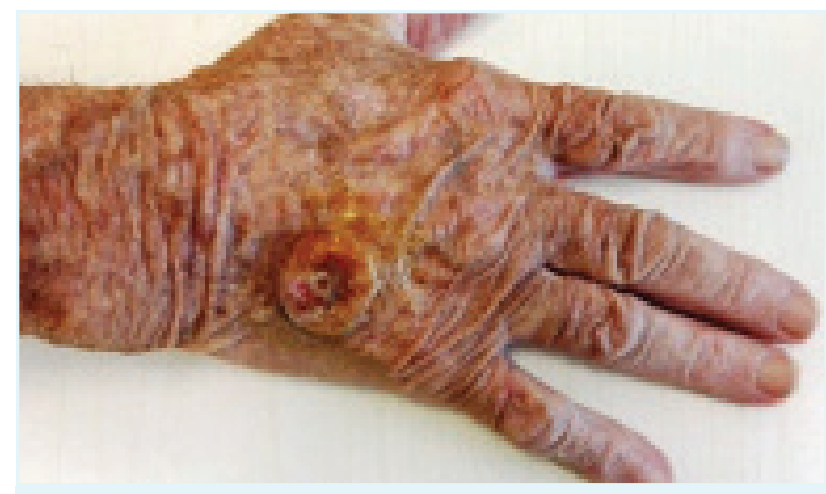

FIGURA 1. Nódulo ulcerado coberto por crosta no dorso da mão direita.

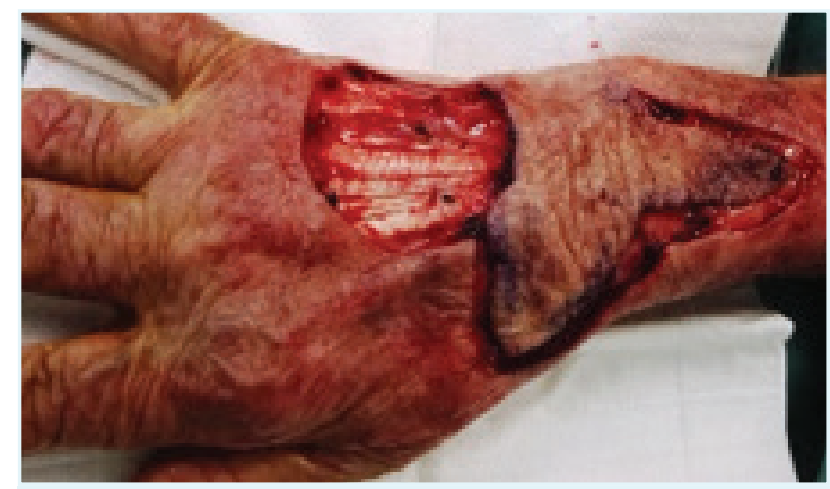

FIGURA 2. Defeito cirúrgico circular com exposição de fáscia e bainhas tendinosas e retalho bilobulado dissecado.

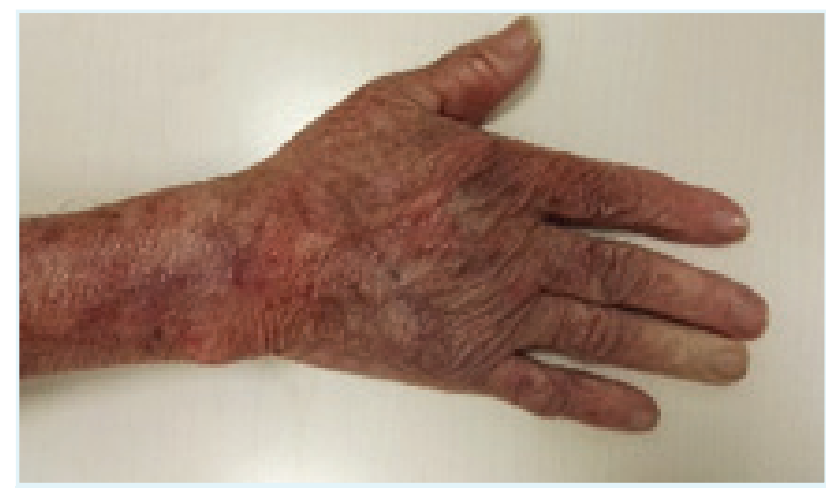

FIGURA 3. Resultado estético aceitável três meses depois, sem limitação funcional.

grandes dimensões podem ser encerrados com bom resultado estético e funcional.

As outras opções cirúrgicas possíveis nesta localização incluem cicatrização por segunda intenção, enxerto de pele e os retalhos locais de rotação, avanço e transposição. ${ }^{4-6}$

APRESENTAÇÕES E PRÉMIOS: Apresentado como poster no $5^{\circ}$ Curso de Cirurgia e Cosmética Dermatológica, Coimbra 13 e 14 outubro 2017.

CONFLITOS DE INTERESSE: Os autores declaram não ter qualquer conflito de interesse na realização do presente trabalho.
FONTES DE FINANCIAMENTO: Não houve qualquer fonte de financiamento na realização do presente trabalho.

CONFIDENCIALIDADE DOS DADOS: Os autores declaram ter seguido os protocolos da sua instituição acerca da publicação dos dados de doentes.

PROTEÇÃO DE PESSOAS E ANIMAIS: Os autores declaram que os procedimentos seguidos na elaboração do presente trabalho estão em conformidade com as normas das comissões de investigação clínica e de ética, bem como da declaração de Helsínquia e da Associação Médica Mundial.

PRESENTATIONS AND PRIZES: Presented as poster at $5^{\circ}$ Curso de Cirurgia e Cosmética Dermatológica, Coimbra, October 13 e 14, 2017.

CONFLICTS OF INTEREST: The authors declare that they have no conflicts of interest.

FINANCIAL SUPPORT: This work has not received any contribution, grant or scholarship.

CONFIDENTIALITY OF DATA: The authors declare that they have followed the protocols of their work center on the publication of data from patients.

PROTECTION OF HUMAN AND ANIMAL SUBJECTS: The authors declare that the procedures followed were in accordance with the regulations of the relevant clinical research ethics committee and with those of the Code of Ethics of the World Medical Association (Declaration of Helsinki).

\section{REFERÊNCIAS}

1. Cerqueiro-Mosquera J, Fleming AN. The bilobed flap: a new application in the reconstruction of congenital thumb deviation. J Hand Surg Br. 2000;25:262-65.

2. Tissiani LAL, Alonso N, Carneiro MH, Bazzi K, Rocco M. Versatility of the bilobed flap. Rev Bras Cir Plást. 2011;26:411-17.

3. Tostes RO, Amorim WC, Morici AF, Silva LC, Júnior JC, Mendonça AC. Biloted flap: a new option in the partial reconstruction of the breast. Rev Soc Bras Cir Plást. 2006;21:88-96.

4. Tavares E, Castellano DP, Rosa J. Retalho de avanço V-Y de pedículo proximal para encerramento de defeito cirúrgico do dorso da mão. Rev Soc Port Dermatol Venereol. 2012;70:34547.

5. Cardoso PM, Santos P, Azevedo F. Rotation flap for closure of surgical defect on the dorsum of the hand. Surg Cosmet Dermatol. 2011;3:348-49. doi: 10.1093/jscr/rjv139.

6. Pontello Júnior R, Kondo RN, Pontello R. The use of the AT flap for reconstructing surgical wounds on the dorsum of the hand. Surg Cosmet Dermatol 2013;5:27072. 